\title{
Obituary
}

\section{In memoriam Jan J. Barkman (1922-1990)}

On Friday 14 September 1990 professor Jan J. Barkman suddenly died while on a working visit to Scotland. He had presented a lecture at a meeting of the British Ecological Society and had joined a field excursion. Quite unexpectedly he was struck by heart failure.

Jan Barkman was a very loyal and cordial friend and a most remarkable person. He had a strong personality, was outspoken and could be exacting, strict and demanding. But he was also kind, approachable and cheerful, and most sincere and reliable. When criticized he never became resentful. On the contrary, he had an open mind; he was prepared to expose himself to deviating opinions and could be persuaded to modify his points of view when he had satisfied himself of the validity of the arguments being brought forward. Actually, Jan Barkman was strongly intellectual, rationalizing and very knowledgeable and he simply loved debating. His memory was phenomenal, he had an astonishingly wide set of facts and figures readily available and he was gifted with an ability to clearly formulate his points of view. To present a flood of clear and convincing data and logical thoughts and illustrate this with a wealth of rapidly

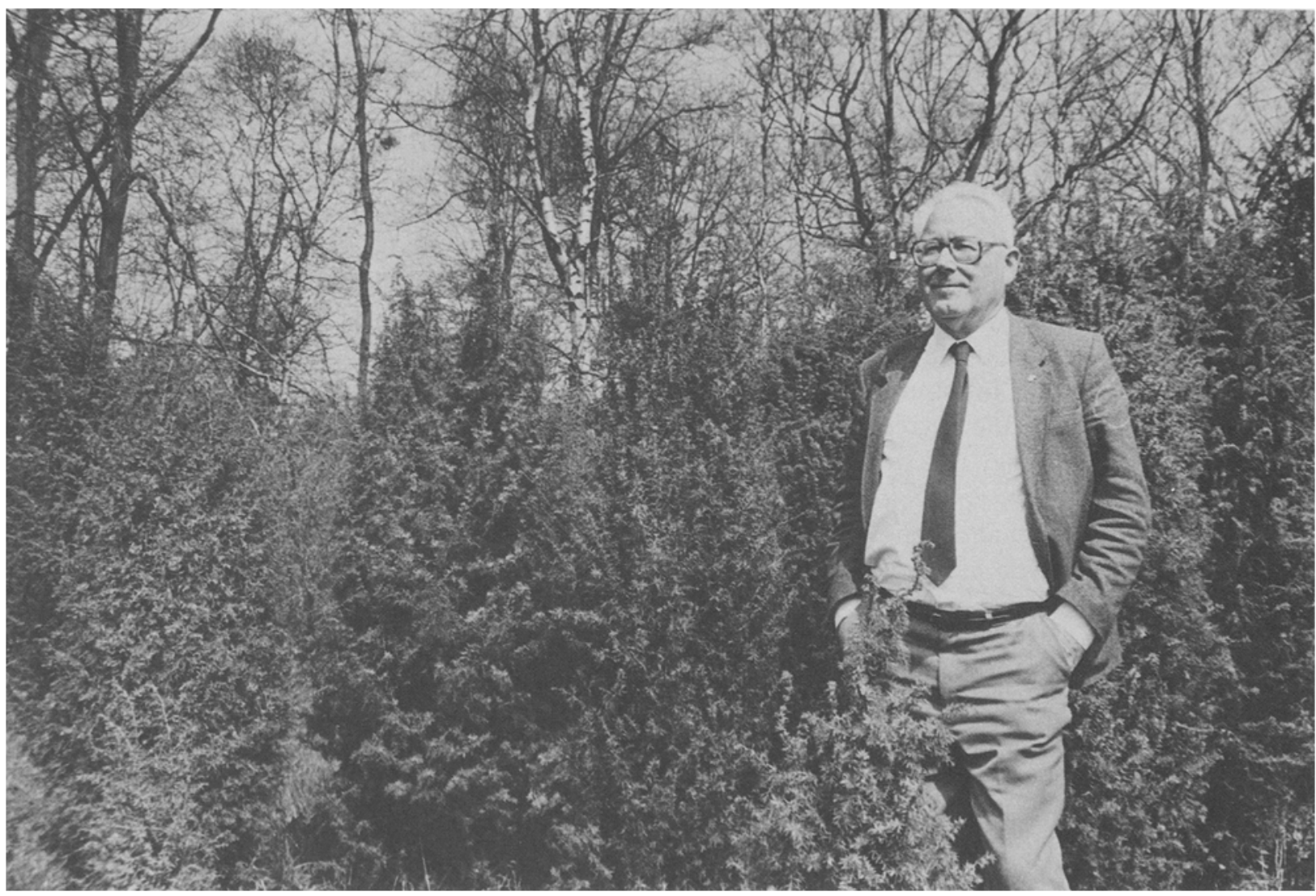

Jan J. Barkman (photo Erik Hardeman) 
imagined examples, some of which could be very funny, came naturally to him. Indeed, Jan Barkman had a keen sense of humour that he easily mixed with his scientific approach to matters. At dinner parties, which he absolutely loved, he could argue in depth and with persistence on scientific issues, but once he noticed that his environment got distracted, he was immediately prepared to switch to, e.g., singing the Raeto-Romanic 'national hymn' in its original wording, or tell some hilareous stories that had happened to him. And because of his imagination, sparkling wit and daring there were quite some stories. We spent many such lively and joyful evenings with Jan Barkman.

Science was Barkman's love and dedication. He interrupted his scientific activities only for another passion of his: playing bridge. He was a very intelligent, stimulating, hard working and versatile scientist and he had a broad interest. He was imaginative in formulating research questions and innovative in developing simple but workable, useful research methods for field measurements. His interest was mainly in field situations and although he recognized and emphasized the value of garden, greenhouse and laboratory experiments, he could not often be seen in those environments. While teaching junior courses he could be pushing but to interested students and beginning scientists he was a very stimulating teacher, scholarly and witty, and prepared to spend a lot of time to get ideas across and analyse research questions.

His emphasis was clearly on pure science. In an interview for the Utrecht university journal he even proudly stated that as soon as something scientific became socially relevant, he lost interest in it. But this was not the complete truth. Jan Barkman was, for instance, an ardent nature conservationist. He was active on many local nature conservational meetings and he served on the National State Advisory Council for Nature Conservation (NWC). One of his great achievements was his success in persuading the government body in charge to divert the track of a planned highway in order to preserve the locality of a rare fungus.

Jan Barkman disliked bureaucracy and he tried to get around it, minimize it or pass it on, but he had to take care of a considerable share in it in his capacity of Director of the Biological Research Station at Wijster. When he was tired of his bureaucratic duties he played the piano to relax; he played classical music.

Jan Barkman was born on 15 March 1922 at Medemblik, the Netherlands. As a child he was very interested in nature: at five he had already a substantial herbarium and later he was an active member of the Nederlandse Jeugdbond voor Natuurstudie (Dutch Youth Naturalists League). He finished his secondary education in Alkmaar in 1939 with extremely high marks for the natural sciences and then started his study in biology, first at the University of Leyden, then at Utrecht. In 1943 the war situation forced him to interrupt his studies. After the war he continued in Leyden and Zürich, Switzerland. In 1949 he was awarded the degree of doctorandus (equivalent to a master degree) majoring in botany, zoology and meteorology (microclimatology). He then joined the staff at Leyden University, initially teaching plant taxonomy and as from 1956 vegetation science. He also conducted floristic and ecological research on cryptogamic epiphyte communities. In 1952 he studied for three months with Josias Braun-Blanquet at Montpellier, France. In 1957, while keeping his teaching obligations at Leyden, he joined the staff of the Agricultural University, Wageningen, in the function of scientist and Head of the Biological Research Station at Wijster. In this function he was the successor to dr. W. Beyerinck. Soon he was promoted to senior scientist.

In 1959 he obtained his Ph.D. cum laude at Leyden University under the supervision of prof. H. J. Lam. His thesis was part of his classic, major book 'Phytosociology and ecology of cryptogamic epiphytes', published in 1958 by Van Gorcum, Assen, and reprinted there in 1970. This work made him famous. It contains a fundamental study on methods to analyse and classify cryptogamic epiphyte communities, a phytosociological classification of those communities for north-western Europe with phytogeographical annotations, and a thorough analysis of several environmental factors correlating with the occurrence of the epiphyte communities. Later, he often jokingly said that he would never have started 
this study, had he anticipated that its results would have been so relevant for environmentalists assessing the impact and extent of air pollution. In the late sixties, however, he initiated and strongly stimulated a project to re-map the 'epiphyte deserts' in the Netherlands.

In Wijster Jan Barkman started two lines of research which he pursued until the end of his life and with which he became identified: mycosociology and the ecology of juniper scrub. In mycosociology he developed, along Braun-Blanquetian lines, his own school, studying the composition and dynamics of fungus communities and linking these with plant communities and with environmental conditions. This also led him to publish several taxonomical revisions on fungal groups. In his later years he extended his ecological knowledge on fungi to studies of the effects of airborne pollutants and acid rain on mycorrhiza.

The study into the ecology of juniper scrub concerned the variation in floristic composition, structure, and habitat characteristics of this open scrubby formation over the whole of north-western, northern and central Europe. Variation in microclimatic conditions inside this open formation was studied and its significance was demonstrated by transplantation experiments with mosses and with litter translocation experiments. Jan Barkman always kept a keen interest in microclimatic measurements in vegetation and this ultimately resulted in a very attractive textbook (with Ph. Stoutjesdijk, 1987, Pudoc, Wageningen). This book is soon to appear in English.

In 1973 Jan Barkman was offered a part-time, and soon afterwards a full professorship in vegetation ecology at Utrecht University. But he did not want to leave Wijster altogether and he decided to divide his time between there and Utrecht. Therefore he accepted only a part-time position in Utrecht where he used to teach students and stimulate his small research group working on a rather broad range of research topics. At the same time he stopped teaching at Leyden.

Perhaps originating from his studies on cryptogamic synusiae, or as a result of his microclimatological measurements, he became more and more interested in the ecological aspects of vegetation structure and plant form. This topic was therefore chosen as the theme of a large international symposium held in Utrecht in 1987 upon Jan Barkman's retirement, as a tribute to him and in appreciation of his valuable contributions to vegetation ecology. In the preface of one of the volumes resulting from that symposium some of Jan Barkman's contributions in this field are pointed out (see Werger et al. (eds.), 1988, Plant form and vegetation structure. SPB Acad. Publ., The Hague). During his appointment at Utrecht University Jan Barkman developed a purely morphological classification system of plant growth forms for the north-western European flora, a classification system of phenological plant forms, a classification system of vegetation structure for all vegetation types of the Netherlands, and a classification system for leaf inclinations. While intensifying his interest in vegetation structure, he also stayed active in the fields he had earlier pursued: he remained a respected and well-informed phytosociologist and an authority on vegetation nomenclature. In fact he was one of the originators and a driving force behind the internationally accepted rules of nomenclature for vegetation units, and for many years he served as the President of the international commission on nomenclature. Of course, he was a prominent person, a board member, and later, a vice-president of the International Association for Vegetation Science. For several years he also was an editor of Vegetatio, and recently he joined the chief editorial committee of the new Journal of Vegetation Science. Jan Barkman published some 140 papers and books.

His broad ecological interest, his very large floristic knowledge, his energy and his enthousiasm made Jan Barkman a lively and excellent excursion leader. Most of these features, as well as his eloquence made him also a much appreciated speaker and lecturer at many symposia and lecture tours. Jan Barkman travelled quite frequently, though mainly within Europe. Particularly northern and eastern Europe, including the Sovjet Union, had his interest, and he visited America only three times. In 1985 he surprised everybody around him by participating in a five-weeks expedition to Svalbard (Spitsbergen), Hopen and Beren Island. There he carried out studies on the vegetation structure and microclimate of some tundra communities, started mycosociological research in the tundra, and had some amazing adventures involving polar bears. 
Also after his retirement he remained active and lively, writing papers and teaching courses in Siena, Leningrad, Tartu and elsewhere, and always returning home with enthousiastic and funny stories. Jan Barkman really enjoyed his life. Unfortunately he died too early. He still had so much energy and so many excellent ideas and he still planned to contribute so much more. It is sad and a great loss that we have to continue without him.

Marinus J. A. Werger \& Victor Westhoff

Utrecht \& Groesbeek, The Netherlands 